\title{
EPIDEMIOLOGICAL CLINICAL INDEX FOR COMMUNITY HEALTH WORKERS IN MALARIA CASE EARLY DETECTION IN EAST NUSA TENGGARA
}

\author{
Pius Weraman \\ Masters Program in Public Health, Universitas Nusa Cendana, \\ Kupang, East Nusa Tenggara
}

\begin{abstract}
Background: East Nusa Tenggara (NTT) is the province with the highest malaria morbidity rate in Indonesia. The Provincial Health Office reported that Annual Parasite Incidence (API) in 2009 was 31 cases per 1000 inhabitants. Compared with the WHO standard, i.e API $>5 \%$, then almost all districts/cities in NTT were high endemicity areas. The aim of this study was to formulate the clinical index of malaria for community health workers for early detection of malaria cases in Lembata Island and Adonara, East Nusa Tenggara.

Subjects and Method: This was an analytic observational study with a crosssectional design. This study was conducted in Lembata and Adonara Island, East Nusa Tenggara from April to December 2014. A sample of 428 cases of malaria based on thick drip blood examination was selected for this study by stratified random sampling. The independent variables were symptoms and clinical signs of malaria. The dependent variable was thick drip blood examination of malaria. The data were collected by questionnaire and analyzed by a multiple logistic regression.

Results: Seven variables predicted malaria case: long fever $(\mathrm{OR}=2.40 ; 95 \% \mathrm{CI}=$ 2.20 to $5.75 ; \mathrm{p}<0.001)$, chill $(\mathrm{OR}=2.80 ; 95 \% \mathrm{CI}=1.19$ to $3.69 ; \mathrm{p}=0.011)$, sweating $(\mathrm{OR}=2.8 ; 95 \% \mathrm{CI}=1.19$ to $3.6 ; \mathrm{p}=0.014)$, back pain $(\mathrm{OR}=2.40 ; 95 \% \mathrm{CI}=1.11$ to $3.51 ; \mathrm{p}=0.054)$, sore throat $(\mathrm{OR}=3.80 ; 95 \% \mathrm{CI}=2.17$ to $5.85 ; \mathrm{p}<0.001)$, bitter mouth $(\mathrm{OR}=3.60 ; 95 \% \mathrm{CI}=2.09$ to $5.18 ; \mathrm{p}=0.011)$, pale face $(\mathrm{OR}=4.20 ; 95 \%$ $\mathrm{CI}=3.31$ to $6.77 ; \mathrm{p}<0.001$ ). The ROC curve had a sensitivity of $80.1 \%$ and a specificity of $66.2 \%$.
\end{abstract}

Conclusion: Seven variables can be used to predict malaria cases: long fever, chill, sweating, back pain, sore throat, bitter mouth, and pale face.

Keywords: epidemiological clinical index, malaria case, early detection, community health worker.

\section{Correspondence:}

Pius Weraman. Masters Program in Public Health, Universitas Nusa Cendana, Kupang, East Nusa Tenggara. 